(1)

\title{
Overexpressed D2 Dopamine Receptor Inhibits Non-Small Cell Lung Cancer Progression through Inhibiting NF-kB Signaling Pathway
}

\author{
Xiao-Yuan Wu ${ }^{\mathrm{a}}$ Chen-Xi Zhang ${ }^{\mathrm{a}}$ Li-Chun Deng ${ }^{\mathrm{b}}$ Jie Xiao ${ }^{\mathrm{a}}$ Xin Yuan ${ }^{\mathrm{c}}$ \\ Bin Zhang ${ }^{\mathrm{a}}$ Zhi-Bo Hou ${ }^{\mathrm{d}}$ Zhi-Hong Sheng ${ }^{\mathrm{a}}$ Lan Sun ${ }^{\mathrm{a}}$ Qi-Chen Jiang \\ Wei Zhao ${ }^{\mathrm{a}, \mathrm{f}}$ \\ ${ }^{a}$ Central Laboratory, Nanjing Chest Hospital, School of Medicine, Southeast University, Nanjing, \\ bDepartment of Oncology, The Affiliated Jiangyin Hospital of Southeast University Medical College, \\ Jiangyin, 'Department of Infectious Disease, the Affiliated Hospital of Nanjing University of Chinese \\ Medicine, Nanjing, 'First Department of Respiratory Medicine, Nanjing Chest Hospital, School of \\ Medicine, Southeast University, Nanjing, ${ }^{e}$ College of Life Sciences, Nanjing Normal University, Nanjing, \\ fDepartment of Clinical Biochemistry, School of laboratory medicine, Chengdu medical college, \\ Chengdu, China
}

\section{Key Words}

DRD2 $・$ NSCLC $・$ Proliferation $•$ Growth $・ N F-k B$ signaling pathway• Clinic outcome

\begin{abstract}
Background/Aims: Non-small cell lung cancer (NSCLC) is one of the deadliest cancers worldwide. Dopamine receptor D2 (DRD2) has multiple roles in clinical progression of NSCLC and functional maintenance of cancer cells. However, little is known about the molecular mechanism. Here, we clarified whether DRD2 inhibits lung cancer progression and identified the underlying downstream signaling. Methods: DRD2 mRNA and protein levels were detected in clinical specimens by qRT-PCR and immunohistochemistry, respectively. MTT and colony formation assays were applied to analyze cell proliferation. The underlying molecular mechanism was identified by dual luciferase, western blot, qRT-PCR, CAMP detection, immunoprecipitation, and chromatin immunoprecipitation assays. A murine NSCLC model was used to clarify the role of DRD2 in tumor cell proliferation. Results: We found that DRD2 ablated tumor cell growth. DRD2 expression in NSCLC tissues was lower than in adjacent normal lung tissues. Moreover, DRD2 mRNA and protein levels in NSCLC were negatively correlated with the tumor size, TNM status, and patient overall survival. In vitro experiments showed that disruption of DRD2 promoted the proliferation of NSCLC cell lines A549 and SK-MES-1 by inhibiting the NF-KB signaling pathway. Furthermore, DRD2 overexpression not

X.-Y. Wu, C.-X. Zhang and L.-C. Deng contributed equally to this work.

Wei Zhao

and Qi-Cheng Jiang

Central Laboratory, Nanjing Chest Hospital, School of Medicine, Southeast University

Nanjing (China)

E-Mail zw198626520@126.com; qcjiangnjnu@gmail.com
\end{abstract}




\section{Cellular Physiology Cell Physiol Biochem 2018;48:2258-2272 \\ \begin{tabular}{ll|l} 
DOI: 10.1159/000492644 & $\begin{array}{l}\text { O 2018 The Author(s). Published by S. Karger AG, Basel } \\
\text { www.karger.com/cpb }\end{array}$
\end{tabular} \\ Wu et al.: DRD2 Inhibits NSCLC Progression by Abrogation of NF-KB Pathway}

only blocked lipopolysaccharide-induced A549 and SK-MES-1 cell proliferation and growth, but also inhibited the tumorigenesis in murine xenograft models. Conclusion: These results indicate that DRD2 may be a potential therapeutic target for lung cancer patients with high DRD2 expression by ablating the NF-KB signaling pathway.

(C) 2018 The Author(s)

Published by S. Karger AG, Basel

\section{Introduction}

Lung cancer is the leading cause of cancer-related mortality worldwide, and non-small cell lung cancer (NSCLC) comprises approximately 85\% of lung cancers [1, 2]. Despite increasing advances focusing on the diagnosis and treatment of NSCLC subsets, improvement in the majority of patients has been very modest. In fact, the overall 5 -year survival rate of NSCLC patients is still less than 20\% [1]. Recently, emerging immunotherapies for this recurrent cancer have gained attention [3, 4]. Differing from traditional therapies including chemotherapy, radiotherapy, and their combinations with angiogenesis inhibitors, immunotherapies primarily target the rapidly dividing tumor cells by affecting key molecular events that drive tumor cell growth and invasion. Therefore, identifying the key molecular mechanisms underlying NSCLC progression is urgently needed to determine therapeutic targets for this disease.

Dopamine receptors (DRD1-5) mainly reside in the human brain, which play important roles in cancer tumorigenesis and progression [5-9]. DRD2 agonists inhibit the growth of lung cancer cells including NSCLC and small cell lung cancer $[6,10,11]$. Recently, DRD2 was found to be highly expressed in CD133+ adenocarcinoma NSCLC cells, and activation of DRD2 inhibited their proliferation, clonogenic ability, and invasiveness by suppressing extracellular signal-regulated kinases $1 / 2$ and AKT, which was accompanied by downregulation of octamer-binding transcription factor 4 expression and matrix metalloproteinase- 9 secretion [7]. Thus, DRD2 has multiple roles in NSCLC, and the biological functions of DRD2 in NSCLC cells, especially the underlying mechanisms, require further study.

The NF- $\kappa B$ signaling pathway is a well-studied pathway that induces expression of more than 200 genes involved in diverse processes including cell survival, adhesion, differentiation, and inflammation [12]. Activation of NF- $\kappa B$ promotes NSCLC tumorigenesis in mice and significantly correlates with advanced TNM stages and poor prognoses of NSCLC patients $[13,14]$. Moreover, the NF- $\mathrm{BB}$ signaling pathway has been demonstrated to be associated with lung cancer initiation, invasion, and cancer stemness maintenance $[15,16]$. Dopamine attenuates protein kinase A (PKA) activation that is initiated by downregulating the cellular level of cyclic AMP (cAMP). In addition, PKA upregulates the NF- $\kappa B$ pathway by phosphorylating p65 on serine $276[17,18]$. Moreover, activation of DRD2 suppresses nuclear translocation of NF- $\mathrm{BB}$ in the intracerebral hemorrhage (ICH) mouse model [19]. However, the biological functions of DRD2 in NSCLC patients and regulation of the NF- $\kappa B$ signaling pathway are unclear.

In this study, we observed decreases in the expression of DRD2 in NSCLC tissues in comparison with adjacent normal lung tissues. Furthermore, DRD2 expression was negatively correlated with the tumor size, TNM status, and overall survival, suggesting that DRD2 is an independent risk factor for NSCLC prognosis. Disruption of DRD2 expression promoted the growth of NSCLC cell lines A549 and SK-MES-1, and induced the NF- $\mathrm{B}$ signaling pathway. Furthermore, DRD2 overexpression in tumor cell lines not only blocked lipopolysaccharide (LPS)-induced NF- $\kappa \mathrm{B}$ signals, cell proliferation, and tumor growth in vitro, but also dramatically inhibited murine xenograft tumorigenesis in vivo. In summary, our study demonstrated that DRD2 inhibits NSCLC cell growth by blocking the NF- $\mathrm{BB}$ signaling pathway both in vitro and in vivo, which further indicates that DRD2 is a potential therapeutic target in NSCLC. 


\section{Cellular Physiology Cell Physiol Biochem 2018;48:2258-2272 \begin{tabular}{l|l|l} 
and Biochemistry & $\begin{array}{l}\text { DOI: 10.1159/000492644 } \\
\text { Published online: 15 August, } 2018\end{array}$ & $\begin{array}{l}\text { () 2018 The Author(s). Published by S. Karger AG, Basel } \\
\text { www.karger.com/cpb }\end{array}$ \\
\hline
\end{tabular}

\section{Materials and Methods}

Tissue specimens and clinical data

A total of 113 primary NSCLC tissue specimens were obtained from patients who underwent lung surgery at Nanjing Chest Hospital (Nanjing, China). No cases had been subjected to preoperative chemotherapy. All cases were followed up for at least 3 years. This study was approved by the Institutional Review Board of Nanjing Chest Hospital. Written informed consent was obtained from all participants. The patient characteristics are listed in Table 1.
Table 1. Tissue DRD2 protein level and clinicopathological factors in NSCLC patients. * Statistically significant difference $(\mathrm{P}<0.05)$

\begin{tabular}{|c|c|c|c|c|}
\hline \multirow[b]{2}{*}{ Characteristic } & \multirow[b]{2}{*}{ Number of Patients } & \multicolumn{3}{|c|}{ DRD2 protein level } \\
\hline & & low & high & $\begin{array}{c}\mathrm{P} \\
\text { value }\end{array}$ \\
\hline Age & & & & 0.611 \\
\hline$<60$ & 42 & 18 & 24 & \\
\hline$\geq 60$ & 71 & 31 & 40 & \\
\hline Gender & & & & 0.374 \\
\hline Male & 69 & 26 & 43 & \\
\hline Female & 44 & 23 & 21 & \\
\hline Tumor size $(\mathrm{cm})$ & & & & $0.012 *$ \\
\hline$<3$ & 51 & 12 & 39 & \\
\hline$\geq 3$ & 62 & 37 & 25 & \\
\hline Lymph node metastasis ( $\mathrm{pN}$ ) & & & & 0.577 \\
\hline Positive & 73 & 32 & 41 & \\
\hline Negative & 40 & 17 & 23 & \\
\hline TNM stage & & & & $0.023 *$ \\
\hline I - II & 67 & 23 & 44 & \\
\hline III-IV & 46 & 26 & 20 & \\
\hline
\end{tabular}

\section{Cell culture and establishment of stable cell lines}

Human NSCLC lines A549 and SK-MES-1 were obtained from the American Type Culture Collection (ATCC) (Manassas, VA, USA). Cells were cultured in RPMI 1640 medium containing 10\% fetal bovine serum (FBS) (Hyclone, Beijing, China).

For DRD2 knockdown, the sequences of human DRD2-targeting and negative control siRNAs were $5^{\prime}$-GCAGGATTCACTGTGACATAA-3' (siD2/1), 5'-GGATTCACTGTGACATCTT-3' (siD2/2), and 5'-GGGATCATGGGTGTCATCTAC-3' (siNC). DNA oligonucleotides incorporating the short hairpin RNA (shRNA)-encoding sequences were synthesized by Shanghai GenePharma Co., Ltd. (Shanghai, China) and annealed into double strands by incubation in Annealing Buffer for RNA Oligos (Beyotime Institute of Biotechnology, Haimen, China). Following digestion with BamHI and EcoRI restriction endonucleases (TransGen Biotech Inc., Beijing, China), the double-stranded DNA molecules were inserted into the pGCSineo-GFP lentiviral vector. Successful insertion was confirmed by DNA sequencing. pGCSi-neo-GFP-DRD2shRNA/NC-shRNA plasmid DNA and packaging vectors were transiently transfected into HEK293T cells (ATCC) using Lipofectamine 2000 ( Thermo Fisher Scientific, Carlsbad, CA), according to the manufacturer's instructions. At $48 \mathrm{~h}$ after transfection, supernatants containing lentiviral particles were collected and purified by ultracentrifugation at 70, $000 \times g$ for $2 \mathrm{~h}$ at $4^{\circ} \mathrm{C}$. For transduction, cultured cells were seeded into a six-well plate at a density of $1 \times 10^{5}$ cells/well and cultured for $24 \mathrm{~h}$. Lentiviral particles encoding shRNAs targeting DRD2 or NC shRNA were added to the media of A549 and SK-MES-1 cells, followed by incubation for $24 \mathrm{~h}$. After replacing the culture medium, the cells were incubated for a further $48 \mathrm{~h}$ prior to analyses.

To construct a DRD2-expressing plasmid, full length cDNA of the DRD2 gene was obtained by reverse transcription (forward primer:

CGGGATCCATGGATCCACTGAATCTGTCCTG;

reverse primer:

CCCTCGAGTCAGCAGTGGAGGATCTTCAGGA) and cloned into the pcDNA3.1 (-) vector (Invitrogen). The DRD2 expression plasmid pCDNA3.1-DRD2 and blank vector were transfected into A549 and SK-MES-1 cells, followed by selection using $800 \mu \mathrm{g} / \mathrm{ml}$ neomycin for 21 days.

Western blotting was employed to detect DRD2 levels in all transfected cells to verify successful transfection.

RNA extraction and quantitative real-time-polymerase chain reaction ( $q R T-P C R$ ) analysis

Total RNA was extracted from NSCLC cells using TRIzol@ reagent (Invitrogen, Carlsbad, USA). Reversetranscribed cDNA was obtained with the Prime-Script $®$ RT Reagent Kit (TAKARA Biotechnology, Dalian, China). qRT-PCR analyses were performed with LightCycler@480 SYBR Green I Master (Roche, Welwyn Garden, Swiss). The primer sequences were as follows:

Bcl-2 forward: GGTGGGGTCATGTGTGTGG;

Bcl-2 reverse: CGGTTCAGGTACTCAGTCATCC;

BclXL forward: GAGCTGGTGGTTGACTTTCTC; 


\title{
Cellular Physiology Cell Physiol Biochem 2018;48:2258-2272 and Biochemistry Published online: 15 August, 2018 \begin{tabular}{l|l} 
DOI: 2018 The Author(s). Published by S. Karger AG, Basel \\
www.karger.com/cpb
\end{tabular} \\ Wu et al.: DRD2 Inhibits NSCLC Progression by Abrogation of NF-kB Pathway
}

\author{
Bcl XL reverse: TCCATCTCCGATTCAGTCCCT; \\ TNF $\alpha$ forward: GAGGCCAAGCCCTGGTATG; \\ TNF $\alpha$ reverse: CGGGCCGATTGATCTCAGC; \\ $\beta$-actin forward: CGCTCTCTGCTCCTCCTGTTC; \\ $\beta$-actin reverse: ATCCGTTGACTCCGACCTTCAC.
}

\section{Immunohistochemical analysis}

Clinical specimens and xenografted tumors were fixed in formalin and embedded in paraffin. Tissue sections were prepared for immunohistochemistry (IHC) staining. Briefly, the sections were deparaffinized using a series of graded ethanol solutions. Primary antibodies against DRD2 (Proteintech, Rosemont, IL) and p65 (Cell Signaling Technology, Danvers, MA) were applied overnight at $4^{\circ} \mathrm{C}$. The procedure was followed by streptavidin-peroxidase treatment (ZS-BIO, Beijing China). Staining was developed with DAB chromogen (Boster, Wuhan, China). Finally, immunoreactivity was scored by the nuclear staining intensity as reported previously $[20,21]$ (on a scale of $0-3$ : negative $=0$; weak $=1$; moderate $=2$; strong $=3$ ) $\times$ the percentage of stained cells (positively recorded on an ordered categorical scale: $0=$ zero; $1=1 \%-25 \% ; 2=26 \%-50 \%$; 3 $=51 \%-100 \%$ ), which resulted in a scale of $0-9$. Immunoreactivity was evaluated by a senior pathologist.

\section{Dual luciferase reporter assay}

Cignal Finder 10-Pathway Reporter Arrays (Qiagen) were employed to identify the potential pathway(s) regulated by DRD2 in NSCLC cells, following the manufacturer's instructions.

Cells were seeded on 24-well plates and cultured without antibiotics until $80 \%$ confluence. Then, $\mathrm{NF}-\kappa \mathrm{B}$ luciferase reporter (containing six NF- $\mathrm{\kappa B}$-binding sites) and internal control pRL-TK plasmids were transfected into the cells. After treating the cells as described, the luciferase activities of the cells were measured using a dual luciferase reporter assay kit (Promega). Reporter luciferase activity was normalized to renilla luciferase activity.

\section{Cell viability assay and colony formation in soft agar}

MTT assays were carried out as described previously [22] to examine the proliferation changes of NSCLC cells.

For colony formation in soft agar, $1 \times 10^{3}$ cells were resuspended as single cells in $0.35 \%$ agarose/RPMI 1640 containing $10 \%$ FBS on $0.7 \%$ agarose in the same medium in 6-well plates. Cells were incubated for 14 days, and then colonies were stained overnight with $0.5 \mathrm{mg} / \mathrm{ml} p$-iodonitrotetrazolium violet (Sigma, St. Louis, MO). Colonies of $>100 \mu \mathrm{m}$ in diameter were counted.

\section{Immunoprecipitation (IP), nuclear protein extraction, and western blot analysis}

Immunoprecipitation assays were conducted as described previously [23]. Briefly, transfected cells were lysed in lysis buffer for $30 \mathrm{~min}$, followed by centrifugation at $12,000 \times \mathrm{g}$ for $20 \mathrm{~min}$ at $4^{\circ} \mathrm{C}$ to remove debris. The lysates were incubated with $1 \mu \mathrm{g}$ anti-PKA-C $\beta$ antibody (sc-904, Santa Cruz Biotechnology) for $24 \mathrm{~h}$ at $4^{\circ} \mathrm{C}$, followed by precipitation of protein A/G-agarose beads. For nuclear protein extraction, cells were collected and solubilized with CelLytic ${ }^{\mathrm{TM}} \mathrm{NuCLEAR}^{\mathrm{TM}}$ (Sigma), according to the manufacturer's instructions. Proteins were separated by sodium dodecyl sulfate-polyacrylamide gel electrophoresis and then transferred onto a polyvinyldifluoridine membrane (Millipore, Darmstadt, Germany). The membranes were probed overnight with antibodies against DRD2, p65 (Proteintech,), p-p65 (ser276, 3037 and ser536, 3031; Cell Signaling Technology), or histone H3 (Cell Signaling Technology). An anti- $\beta$-actin antibody (Proteintech) was used for the loading control. Western blotting was visualized using an enhanced chemiluminescence kit (Pierce, Waltham, MA).

\section{Chromatin immunoprecipitation (ChIP)}

ChIP assays were performed using a ChIP assay kit (Millipore), according to the manufacturer's instructions. After nuclear extracts were isolated as described above, an antibody against p65 (3034, Cell Signaling Technology) was used to immunoprecipitate chromatin in nuclear fractions, whereas a nonspecific IgG antibody was used for the negative control. Immunoprecipitated DNA was analyzed by qRT-PCR using specific primers: TNF- $\alpha$ (forward: CCCTCCAGTTCTAGTTCTATC; reverse: GGGGAAAGAATCATTCAACCA). Measurements were made in triplicate. 


\section{Cellular Physiology Cell Physiol Biochem 2018;48:2258-2272

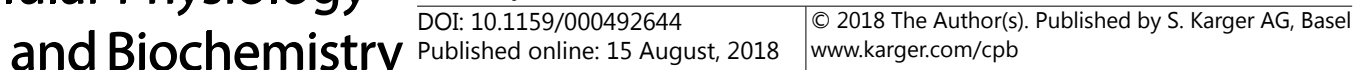

\section{cAMP determination}

A total of $1 \times 10^{4}$ cells/well were seeded in 6-well plates and cultured without antibiotics until $80 \%$ confluence. Cells were then harvested for cAMP detection. cAMP levels were measured in total cell lysates using an enzyme immunoassay kit (Biomol, Heidelberg, Germany), according to the manufacturer's instructions.

\section{Murine xenografts and IHC}

All animal experiments were approved by the Animal Care and Use Committee of Nanjing Chest Hospital. Six-week-old male Athymic mice were housed in a specific pathogen-free facility. Stable A549 and parental cells were suspended in $40 \%$ Matrigel matrix (BD Biosciences)/PBS at a density of $1 \times 10^{7}$ cells/ $\mathrm{ml}$. NSCLC cells $\left(2 \times 10^{6}\right)$ were injected subcutaneously into the flank region of nude mice using $1-3-\mathrm{cm}^{3}$ tuberculin syringes. For drug experiment, quinpirole $(10 \mathrm{mg} / \mathrm{kg})$ was administered to the mice by gavage every day for 5 weeks. The tumor size was measured every 3 days using a caliper, and tumor volume was calculated using the following equation: tumor volume $\left(\mathrm{mm}^{3}\right)=\left(\mathrm{L} \times \mathrm{W}^{2}\right) / 2$, where $\mathrm{L}=$ length and $\mathrm{W}=$ width. At the endpoint, tumors were harvested and weighted.

All animal experiments were approved by the Animal Care and Use Committee of Nanjing Chest Hospital. A549 cells were suspended in $40 \%$ Matrigel matrix/PBS at a density of $1 \times 10^{7}$ cells $/ \mathrm{ml}$. Six-weekold male athymic mice were housed in a specific pathogen-free facility. NSCLC cells $\left(1 \times 10^{6}\right)$ were injected subcutaneously into the flank region of nude mice using $1-3-\mathrm{cm}^{3}$ tuberculin syringes. Quinpirole $(10 \mathrm{mg} /$ $\mathrm{kg}$ ) was administered to the mice by gavage every day for 5 weeks. Tumor size and mouse body weight were measured every 3 days. Tumor size was measured by a caliper, and tumor volume was calculated using the following equation: tumor volume $\left(\mathrm{mm}^{3}\right)=\left(\mathrm{L} \times \mathrm{W}^{2}\right) / 2$, where $\mathrm{L}=$ length and $\mathrm{W}=$ width. At the endpoint, the tumors were harvested and weighted.

Tumor tissues were collected at the end point, fixed in formalin and embedded in paraffin. Tissue sections were prepared for IHC staining. Briefly, the sections were deparaffinized using a series of graded ethanol solutions. A primary antibody against p65 (1:100 dilution) was applied overnight at $4^{\circ} \mathrm{C}$. The procedure was followed by streptavidin-peroxidase treatment. Staining was developed with DAB chromogen. Finally, immunoreactivity was scored as the nuclear staining intensity (on a scale of 0-3: negative $=0$; weak $=1$; moderate $=2$; strong $=3$ ) $\times$ the percentage of stained cells (positively recorded on an ordered categorical scale: $0=$ zero; $1=1 \%-25 \% ; 2=26 \%-50 \% ; 3=51 \%-100 \%$ ), which resulted in a scale of $0-9$. Immunoreactivity was evaluated by a senior pathologist.

\section{Statistics analysis}

The Student's t-test (two-tailed, parametric test for normal distribution) or Mann-Whitney $U$-test (non-parametric test for non-normal distribution) were performed as appropriate to compare intergroup differences after a distribution check. Adjustments for multiple comparisons were made using the false discovery rate.

Overall survival (OS) was analyzed by the Kaplan-Meier method and Log-rank test. The High DRD2 group was defined by an IHC value that was higher than that of the median of total NSCLC tumors, and the low DRD2 group was lower than the median value.

SPSS software 19.0 version (SPSS Inc., Chicago, IL) and GraphPad Prism 6 (GraphPad Software, Inc, San Diego, CA) were used for statistical analysis. $P<0.05$ was considered as statistically significant.

\section{Results}

Decreased expression of DRD2 in NSCLC tumor cells negatively correlates with clinicopathological features

Previous studies have reported that activation of DRD2 signaling correlates with inhibition of lung cancer progression [6]. To further investigate the role of DRD2 in NSCLC, we first measured the expression of DRD2 in 113 specimens of NSCLC tissues. Among 90 paired clinical samples, 62 adenocarcinoma specimens showed reduced DRD2 mRNA expression $(\geq 50 \%)$ compared with the adjacent normal tissues, and 11 adenocarcinoma specimens had increased DRD2 mRNA expression ( $\geq 50 \%$ ) (Fig. 1A, top panel). In the squamous cell 


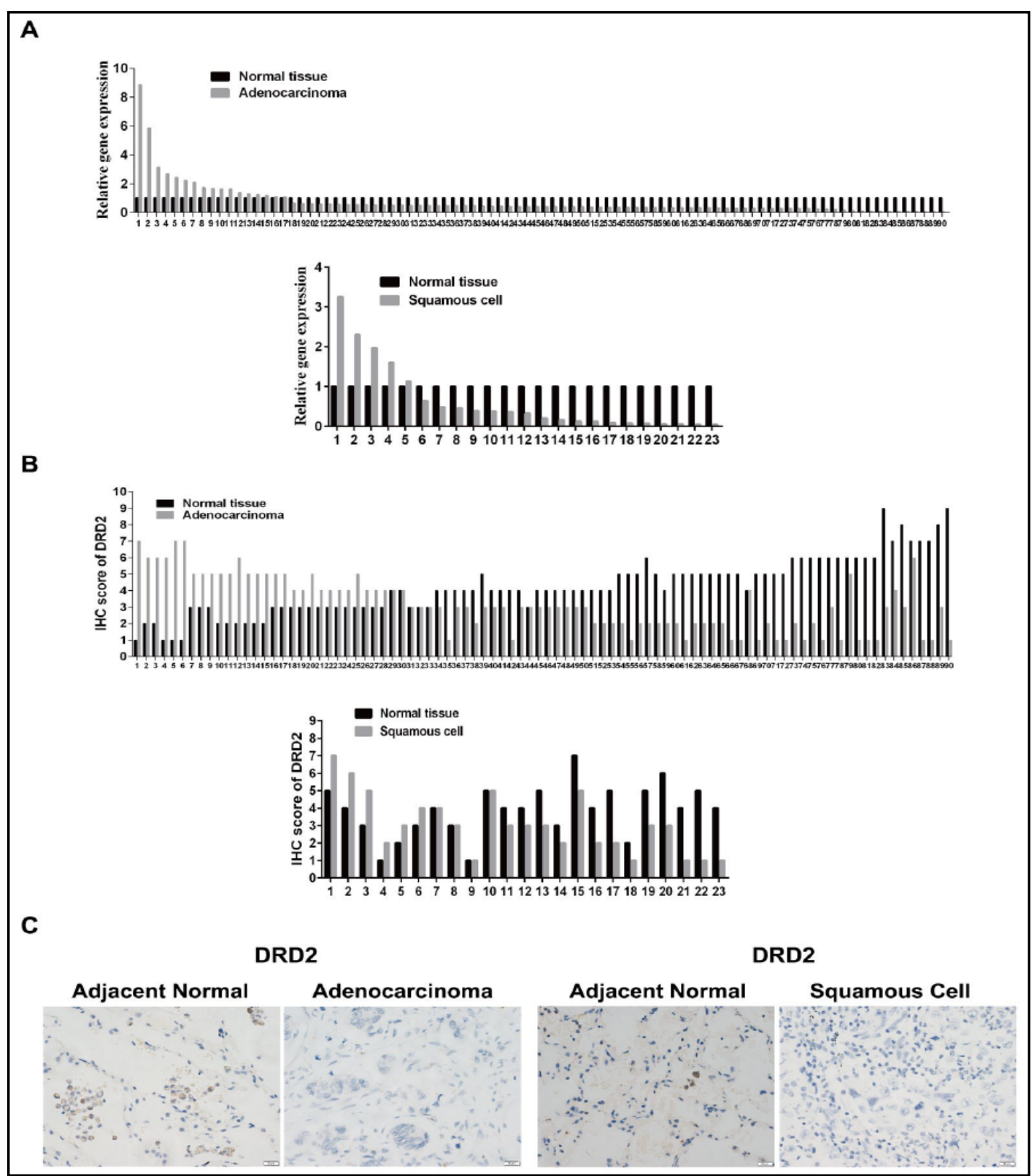

Fig. 1. DRD2 expression in patient specimens. (A) DRD2 mRNA levels in paired clinical specimens of adenocarcinoma (90 pairs) and squamous cell carcinoma (23 pairs) were determined by qRT-PCR. (B) IHC scores of DRD2 in adenocarcinoma/squamous cell carcinoma and adjacent normal lung tissues. (C) Representative IHC images of DRD2 in clinical specimens.

carcinoma cohort (23 pairs), we observed lower DRD2 mRNA levels in 17 tumors ( $\geq 50 \%)$ and increased DRD2 mRNA levels in four tumors ( $\geq 50 \%$; Fig. $1 \mathrm{~A}$, bottom panel). To confirm the expression of DRD2, we detected DRDR2 protein expression in our specimens by IHC analysis (Fig. 1C). As shown in Fig. 1B, 57 adenocarcinoma and 12 squamous cell carcinoma tissues had lower IHC scores than the paired normal tissues. Moreover, the relationship between DRD2 expression and clinicopathological features was analyzed (Table 1). The results revealed 64 patients in the high DRD2 group and their DRD2 expression was negatively correlated with the tumor size $(P=0.012)$ and TNM stage $(P=0.023)$. Multivariate analysis showed that DRD2 $(P=0.008)$, $\mathrm{N}$ stages $(P=0.023)$, and TNM stages $(P=0.005)$ were independent prognostic factors of NSCLC patients (Table 2). 
Downregulated DRD2 expression promotes NSCLC cell growth in vitro

To determine the effect of DRD2 on tumor cell growth, two tumor cell lines were investigated using shRNA-mediated knockdown. DRD2 expression was downregulated in A549 (adenocarcinoma cell line) and SK-MES-1 (squamous carcinoma cell line) cells (Fig. 2A). MTT assays showed that downregulated expression of DRD2 in A549 and SK-MES-1 cells promoted tumor cell growth and colony formation (Fig. 2B). To verify the effect of DRD2 on NSCLC cell growth, we generated A549 and SK-MES-1 cells with stable expression of DRD2 (Fig. 2C). MTT assays and colony formation in soft agar showed that ectopic DRD2 impaired NSCLC cell proliferation and colony formation (Fig. 2C and D). Therefore, DRD2 may be a potential target to inhibit NSCLC tumor cell growth.

DRD2 abrogates the NF-

$\kappa B$ signaling pathway

To clarify DRD2-mediated downstream signaling pathways in regulating NSCLC cell growth, we examined 10 cancer-related signaling pathways in DRD2overexpressing tumor cells and their parental cells. In DRD2-overexpressing NSCLC tumor cells, expression of NF$\kappa \mathrm{B}$ signaling molecules was
Table 2. Multivariate analyses of DRD2 expression and other clinical prognostic factors in patients with non-small cell lung cancer. Abbreviations: HR, hazard ration; 95\% CI, 95\% confidence interval. *, Statistically significant difference $(\mathrm{P}<0.05)$

\begin{tabular}{lcc}
\hline Factors & HR $(95 \% \mathrm{CI})$ & $\mathrm{P}$ \\
\hline Age $(\geq 60 /<60$ years) & $0.585(0.330-1.039)$ & 0.068 \\
Gender (Femle/Male) & $0.689(0.351-1.353)$ & 0.279 \\
Smoking status (Yes/No) & $2.452(0.414-4.537)$ & 0.743 \\
Size of tumor $(\geq 3 \mathrm{~cm} /<3 \mathrm{~cm})$ & $0.735(0.414-1.303)$ & 0.291 \\
N stage (Positive/Negative) & $1.734(1.383-2.665)$ & $0.023^{*}$ \\
Stage (I and II/III and IV) & $1.932(1.312-2.675)$ & $0.005^{*}$ \\
DRD2 expression (low/high) & $2.125(1.644-2.760)$ & $0.008^{*}$ \\
\hline
\end{tabular}

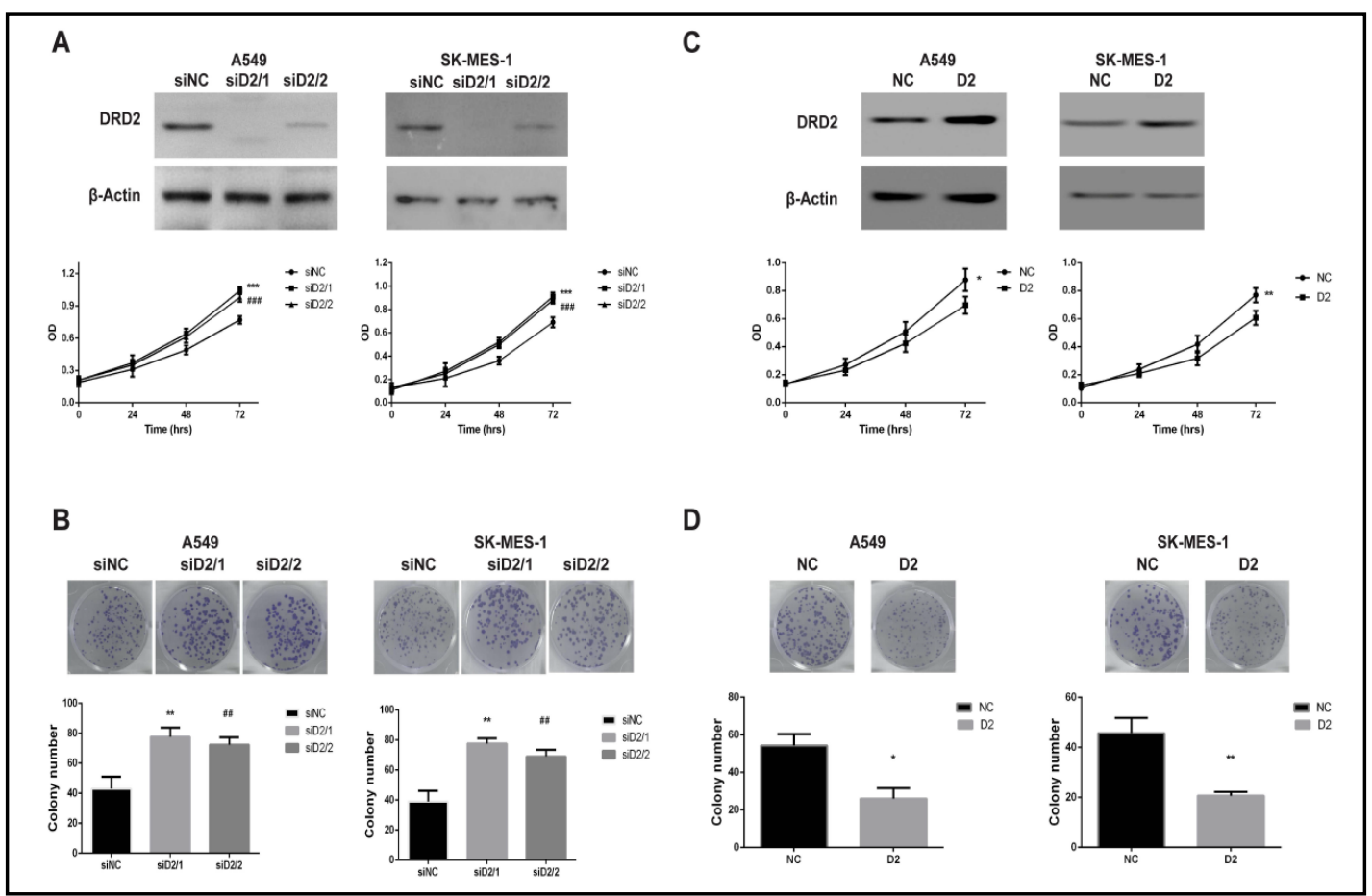

Fig. 2. DRD2 affects NSCLC cell growth in vitro. MTT assays detected the effects of knockdown (A) and overexpression (B) of DRD2 on viability in NSCLC cell lines A549 and SK-MES-1. Colony formation in soft agar validated the effects DRD2 knockdown (C) and overexpression (D) on A549 and SK-MES-1 cell growth in vitro. $\mathrm{NC}$, negative control; $\mathrm{D} 2, \mathrm{DRD} 2 .{ }^{*} \mathrm{P}<0.05,{ }^{* *} \mathrm{P}<0.01,{ }^{* * *} \mathrm{P}<0.001$, siD2 $/ 1$ vs siNC or $\mathrm{D} 2$ vs NC; ${ }^{\# \# \# P<0.001, ~ s i D 2 / 2}$ vs siNC. 


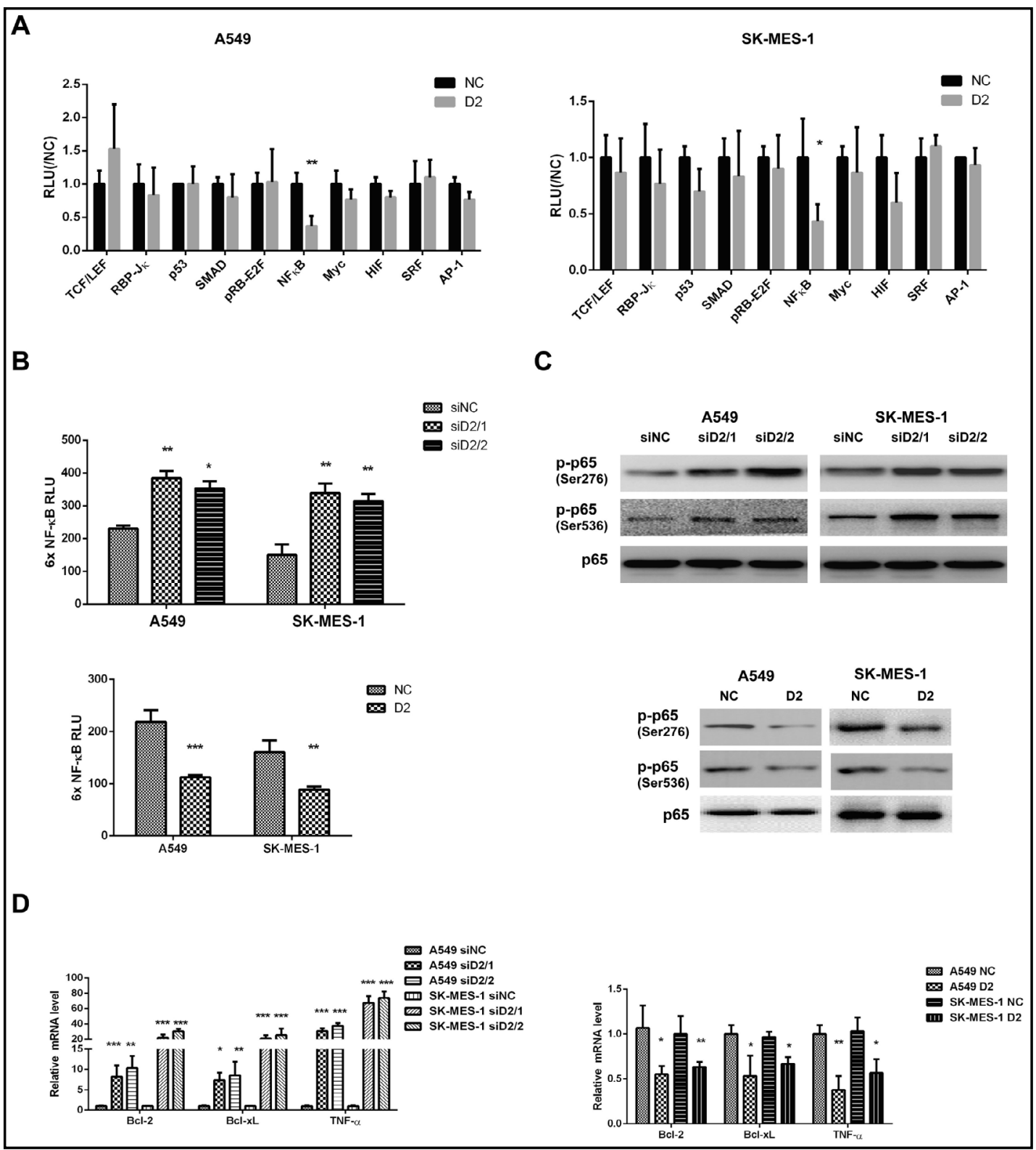

Fig. 3. DRD2 blocks the NF- $\mathrm{B}$ s signaling pathway in NSCLC cells. (A) Cignal Finder 10-Pathway Reporter Arrays to detect changes in 10 cancer-related signaling pathway molecules of DRD2-overexpressing cells compared with their parental cells. (B) Changes in NF- $\kappa$ B activities of DRD2-overexpressing and knockdown cells were confirmed by luciferase assays. (C) Western blotting showed the phosphorylation status of p65 (serine 276 and 536) and total p65 in DRD2-overexpressing and knockdown NSCLC cells, $\beta$-Actin was used as a loading control. (D) Bcl-2, Bcl-xL, and TNF- $\alpha$ mRNA levels were measured in DRD2-overexpressing and knockdown NSCLC cells. ${ }^{*} \mathrm{P}<0.05,{ }^{* *} \mathrm{P}<0.01,{ }^{* * *} \mathrm{P}<0.001$.

dramatically abrogated by $66.67 \%$ in A549 cells and 59.31\% in SK-MES-1 cells (Fig. 3A). In addition, using an NF- $\mathrm{KB}$ luciferase reporter system, we observed that luciferase activity of pGL3-NF- $\kappa \mathrm{B}$ was induced by shRNA-mediated DRD2 knockdown in NSCLC cells, but reduced in DRD2-overexpressing NSCLC tumor cells (Fig. 3B). In parallel, phosphorylated p65 at serine 276 and 536 was upregulated in DRD2-knockdown cells and downregulated in DRD2-overexpressing NSCLC tumor cells (Fig. 3C). Furthermore, we examined the expression of canonical p65-targeted genes Bcl-2, Bcl-xL, and TNF- $\alpha$. The gene expression 
of Bcl-2, Bcl-xL, and TNF- $\alpha$ was upregulated in DRD2-knockdown A549 and SK-MES-1 cells, and downregulated significantly in DRD2-overexpressing A549 and SK-MES-1 cells (Fig. 3D).

DRD2 has been reported to downregulate the level of cAMP required for phosphorylation of p65 by PKA $[17,18]$. To clarify the role of cAMP in regulating the NF-kB signaling pathway, we used knockdown and overexpression approaches, and found that the cellular level of cAMP was reduced by $29.7 \%$ and $17.2 \%$ in DRD2-overexpressing A549 and SK-MES- 1 cells, respectively (Fig. 4A). In contrast, the cellular level of cAMP was increased significantly in DRD2 knockdown NSCLC tumor cells (Fig. 4A). Moreover, we detected the interaction between DRD2 and PKA by IP, indicating that the interaction was interrupted in DRD2-overexpressing NSCLC cells (Fig. 4B, upper panel). Densitometric analysis showed that DRD2 reduces $30.2 \%$ and $71.3 \%$ interaction with PKA in A549 and SK-MES-1 cells. Moreover, p65 had less distribution in NSCLC cell nuclei when the cAMP level and interaction of PKA and p65 were suppressed by DRD2 (Fig. 4C). The TNF- $\alpha$ promoter-binding ability of p65 was decreased in A549/D2 ( $P=0.002)$ and SK-MES-1/D2 ( $P=0.032)$ cells (Fig. 4D). Therefore, DRD2 inhibited NSCLC tumor cell growth by blocking the NF- $\mathrm{KB}$ signaling pathway via regulating the cAMP/ $\mathrm{PKA} / \mathrm{p} 65$ axis.

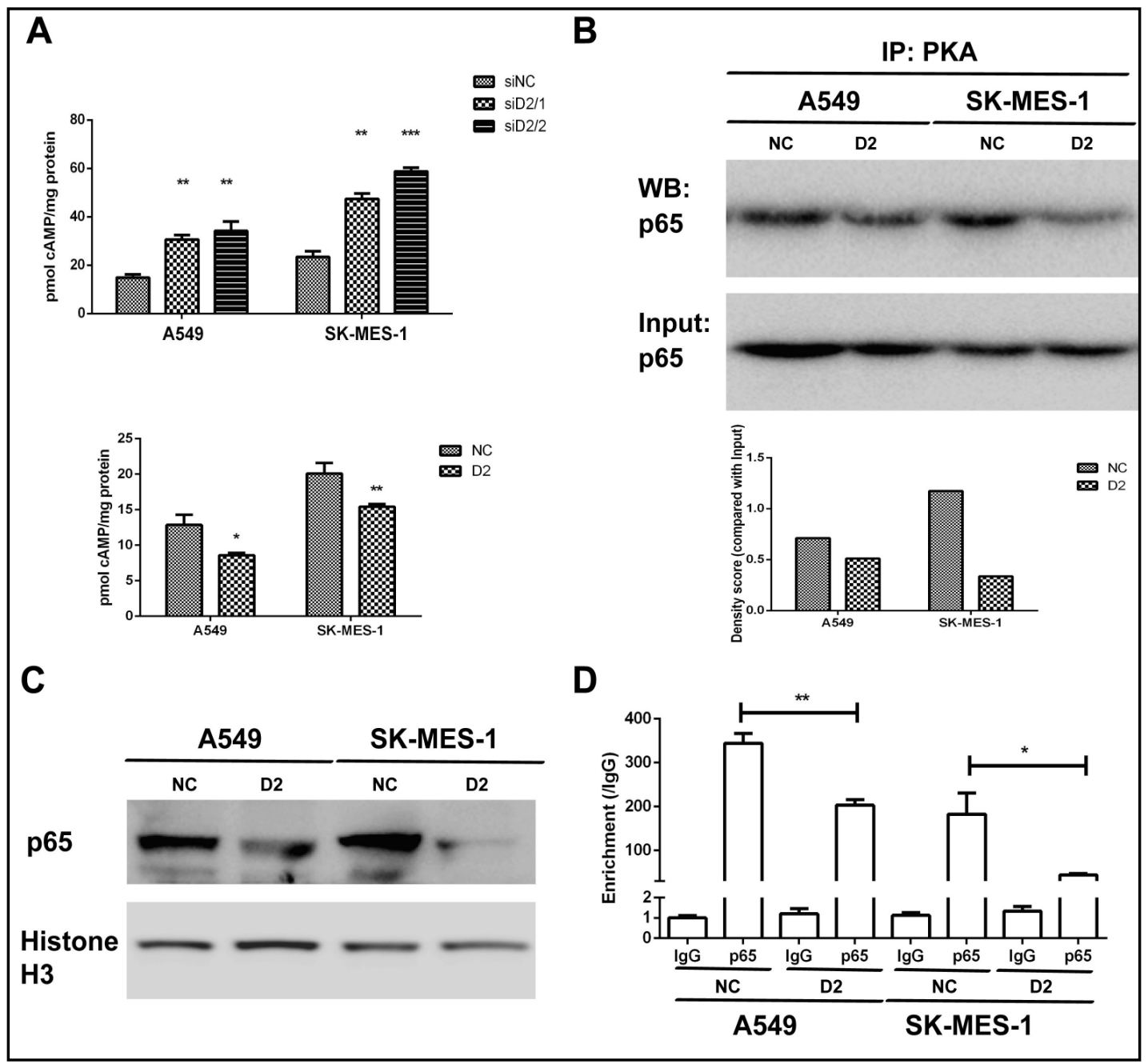

Fig. 4. DRD2 abrogates the cAMP/PKA/p65 axis. (A) Cellular cAMP was detected by an ELISA in DRD2overexpressing and knockdown NSCLC cells. (B) IP assays identified the interaction of PKA and p65 in DRD2-overexpressing A549 and SK-MES-1 cells. Densitometric analysis of IP results by ImageJ is shown. The nuclear p65 distribution (C) and p65-binding ability of the TNF- $\alpha$ promoter were also affected by DRD2 in NSCLC cells. ${ }^{*} \mathrm{P}<0.05,{ }^{* *} \mathrm{P}<0.01,{ }^{* * *} \mathrm{P}<0.001$, vs NC. 
DRD2 overexpression reduces NSCLC cell viability and growth by inhibiting the NF- $\kappa B$ signaling pathway

In the present study, we demonstrated that DRD2 inhibited the NF- $\kappa B$ signaling pathway, cancer cell viability, and tumor growth. However, it was unclear whether inhibition of NSCLC cell viability and growth by DRD2 was mediated through the NF- $\kappa$ B signaling pathway. LPS promotes cancer cell proliferation through the NF- $\kappa B$ signaling pathway [24, 25]. Thus, LPS was employed to induce activity of the NF- $\kappa B$ signaling pathway in NSCLC cells. LPStriggered NF- $\kappa B$ signal activation was abrogated by overexpression of DRD2 in NSCLC cells (Fig. 5A). Similarly, we obtained the same results using the DRD2 overexpression approach. Expression of phosphorylated p65 was reduced in DRD2-overexpressing tumor cells in response to LPS stimulation (Fig. 5B). Furthermore, DRD2 blocked LPS-triggered NSCLC cell proliferation and colony formation in MTT and colony formation assays, respectively (Fig. 5C and D). Taken together, these results suggest that DRD2 inhibits NSCLC cell viability and growth by inhibiting the overactivated NF- $\mathrm{KB}$ signaling pathway.

\section{DRD2 activation correlates with NSCLC tumor progression in vivo}

We found that DRD2 inhibited NSCLC tumor cell growth in the in vitro experiments, suggesting that DRD2 is a promising therapeutic target to inhibit tumor progression. To confirm the biological and therapeutic roles of DRD2 in vivo, a murine xenograft model was established. The tumor volume was significantly decreased in DRD2-overexpressing xenografted tumors after 3 weeks (Fig. 6A). In addition, the tumor size and weight of the DRD2-overexpressing group was significantly smaller and lower than those of the control group $(P=0.0234$; Fig. 6B). Furthermore, we observed decreases in phosphorylated nuclear p65 (Fig. 6C) and mRNA levels of Bcl-2 and TNF- $\alpha$ in DRD2-overexpressing xenografts (Fig. 6D). Here, we also employed quinpirole (a selective DRD2 agonist) to treat NSCLC-

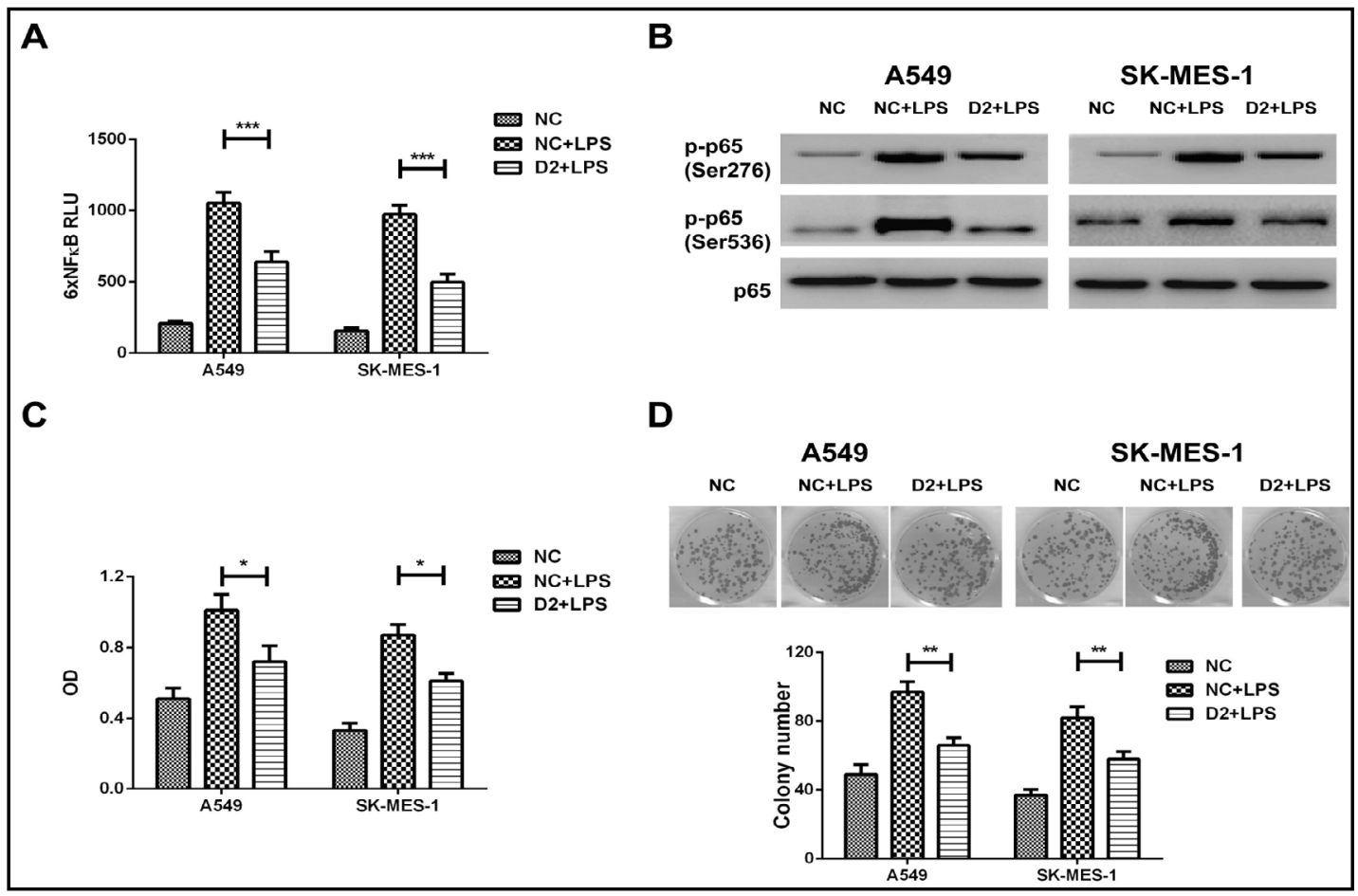

Fig. 5. LPS-induced NF- $\kappa B$ signaling is blocked by DRD2. NF- $\kappa B$ activity was induced by LPS (10 $\mu \mathrm{g} / \mathrm{ml})$ for $8 \mathrm{~h}$ in DRD2-overexpressing A549 and SK-MES-1 cells. (A) Luciferase assays to detect NF- $\mathrm{B}$ activity. (B) Western blotting to examine phosphorylation of p65. (C) MTT assays to detect cell viability changes. (D) NSCLC cells were incubated with $2 \mu \mathrm{g} / \mathrm{ml}$ LPS for 10 days. ${ }^{*} \mathrm{P}<0.05,{ }^{* *} \mathrm{P}<0.01,{ }^{* * *} \mathrm{P}<0.001$. 
Fig. 6. Role of DRD2 in NSCLC tumorigenesis and the NF- $\kappa$ B signaling pathway in vivo. (A) In vivo tumor growth curve of DRD2-overexpressing and control xenografts over 30 days. (B) Size and average weight of xenografted tumors at the end point. (C) Representative p65 staining at $\times 400$ magnification. Bar graphs show the mean \pm SEM of nuclear p65 staining values in xenografted tumors. (D) qRT-PCR to measure Bcl2 , Bcl-xL, and TNF- $\alpha$ mRNA levels in three xenografted tumors of each group. (E) Correlation between the DRD2 level and OS of NSCLC patients analyzed by the Kaplan-Meier method and log-rank test. ${ }^{*} \mathrm{P}<0.05,{ }^{* *} \mathrm{P}<0.01$, $* * * \mathrm{P}<0.001$.

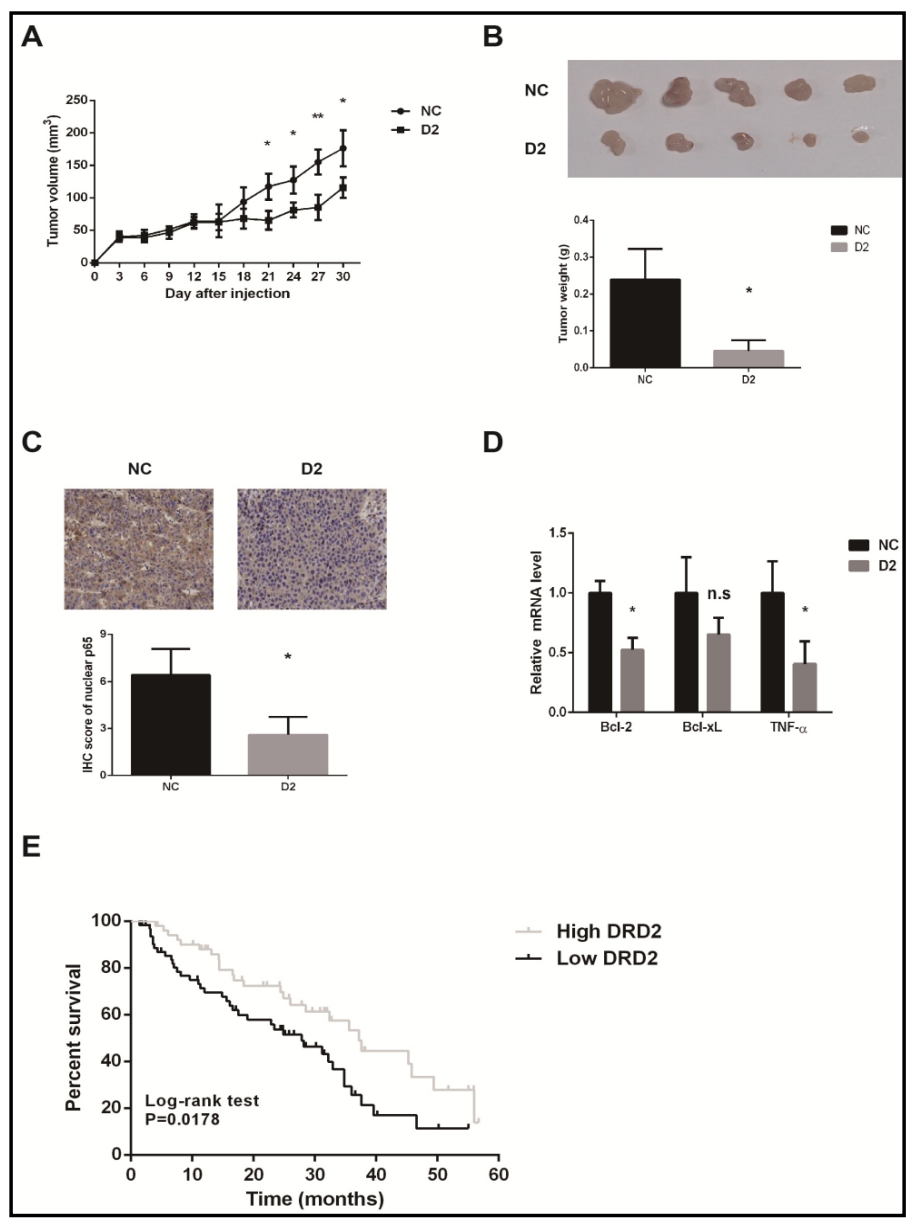

Fig. 7. DRD2 agonist blocks NSCLC tumorigenesis and the NF$\kappa \mathrm{B}$ signaling pathway. (A) Tumor growth curve of NSCLC xenografts in control and quinpirole treatment groups. (B) Size and average weight of xenografted tumors at the end point. (C) Representative p65 staining at $\times 400$ magnification. Bar graphs show the mean \pm SEM of nuclear p65 staining values in xenografted tumors. (D) qRT-PCR to detect of Bcl-2, Bcl$x L$, and TNF- $\alpha$ mRNA levels in three xenografted tumors of each group. (E) Body weights of each group were measured every 3 days. (F) Liver, heart, and spleen weights in each group were measured at the end point. ${ }^{*} \mathrm{P}<0.05,{ }^{* *} \mathrm{P}<0.01,{ }^{* * *} \mathrm{P}<0.001$.

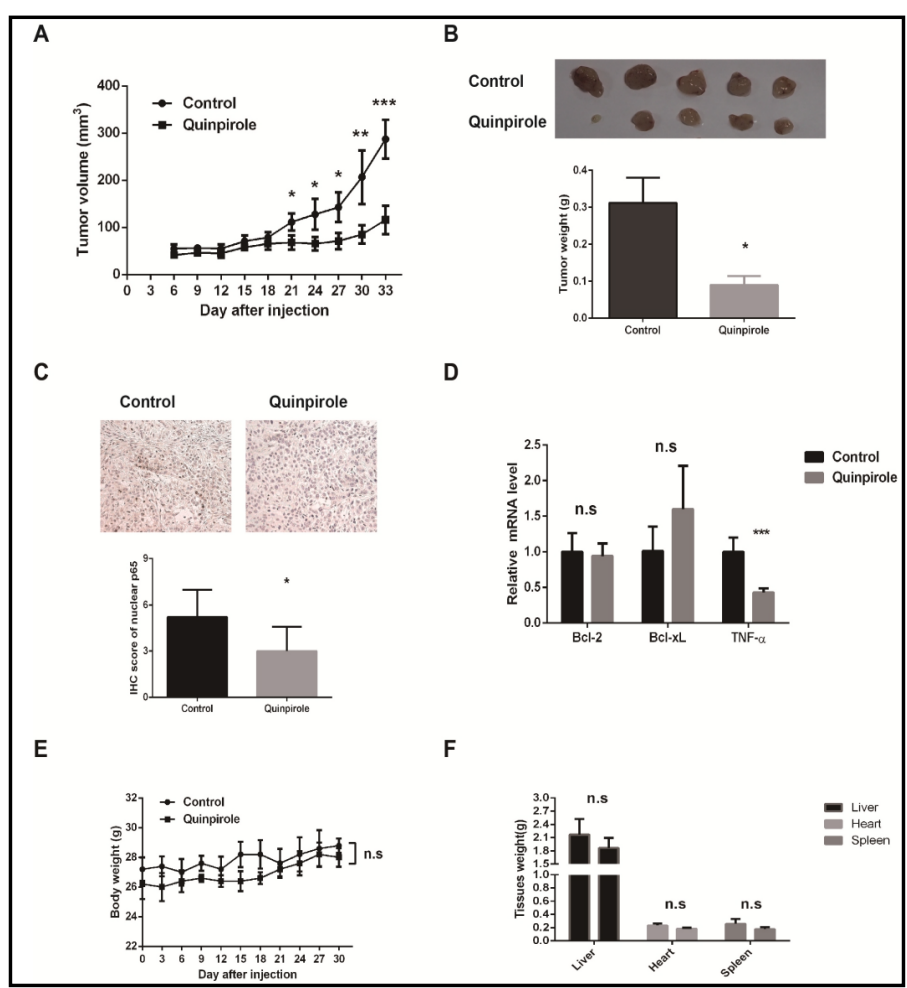




\section{Cellular Physiology Cell Physiol Biochem 2018;48:2258-2272 \\ \begin{tabular}{c|c|c|} 
DOI: 10.1159/000492644 & $\begin{array}{l}\text { O 2018 The Author(s). Published by S. Karger AG, Basel } \\
\text { www.karger.com/cpb }\end{array}$
\end{tabular} \\ Wu et al.: DRD2 Inhibits NSCLC Progression by Abrogation of NF-KB Pathway}

xenografted mice. As shown in Fig.7 A-D, the activation of DRD2 by quinpirole abrogated NSCLC xenograft growth and NF- $\kappa B$ signal. The drug treatment has no effect on mice, livers, hearts and spleens weight (Fig.7 E and F).

Next, we investigated the correlation of DRD2 expression and patient OS. Kaplan-Meier analysis and Log-rank tests demonstrated that patients with higher DRD2 expression had a significantly higher OS rate than patients with lower DRD2 expression $(P=0.0178$; Fig. 6E). Taken together, these results clarified that DRD2 inhibited NSCLC cell tumorigenicity through inhibiting the NF- $\mathrm{KB}$ signaling pathway, suggesting that DRD2 is a potential therapeutic target for NSCLC immunotherapies.

\section{Discussion}

Lung cancer is a frequently diagnosed cancer and NSCLC is the leading cause of lung cancer mortality [26]. Currently, increasing numbers of patients do not respond to traditional chemotherapies and radiotherapy, leading to a poor prognosis and low survival rate [27]. Since the rapid development of immunotherapy, such therapies have been implicated in curing recurrent diseases [28]. Thus, studies should investigate the underlying mechanisms in NSCLC.

Current studies have shown contradictory roles of DRD2 in various solid tumors. Previous reports have demonstrated DRD2 overexpression in breast cancer and esophageal squamous cell carcinoma. Overexpression of the DRD2 gene is significantly associated with the progression of these tumors $[29,30]$. Polymorphisms responsible for reduced DRD2 expression are not only associated with the risk of developing colorectal cancer, but also an increased risk of recurrence of advanced colorectal adenoma [31, 32]. The polymorphisms of DRD2 resulting in lower dopamine bioavailability are associated with an increased risk of developing NSCLC [33]. In the present study, downregulated expression of DRD2 was found in adenocarcinoma and squamous cell carcinoma, the two major histological types of our NSCLC specimens. DRD2 overexpression inhibited A549 tumor growth and NF- $\kappa B$ signaling in vivo, which is consistent with a previous report [6]. Although adenocarcinoma and squamous cell carcinoma have different biological characters [34], we clarified that DRD2 inhibited the NF- $\kappa B$ signaling pathway through the DRD2/PKA axis in both adenocarcinoma (A549) and squamous cell carcinoma (SK-MES-1) cell lines. These results suggest that DRD2 affects NSCLC cellular functions, and targeting DRD2 may be a promising therapeutic strategy for adenocarcinoma and squamous cell carcinoma.

DRD2 agonists have been shown to inhibit lung cancer progression by reducing angiogenesis and tumor-infiltrating myeloid-derived suppressor cells in mice [6]. In Fig. 7, we employed quinpirole to treat NSCLC-xenografted mice. Our data confirmed that quinpirole treatment inhibited NSCLC-xenografted tumor growth and the NF- $\kappa B$ signaling pathway in vivo. The treatment had no effects on the weights of the murine body, liver, heart, or spleen. The above data suggest that quinpirole is a promising and safe drug for NSCLC treatment.

In NSCLC cells, overexpression of DRD2 abrogated cellular cAMP and phosphorylation of p65. PKA is required for phosphorylation of $\mathrm{p} 65$ at serine 276 [18]. Both phosphorylations of p65 at serine 276 and 536 were inhibited in DRD2-overexpressing NSCLC cells. Because of the crosstalk of NF- $\kappa \mathrm{B}$ signaling pathways [12], we hypothesized that phosphorylation of p65 at serine 276 may promote phosphorylation at serine 536 in NSCLC cells. In the ICH mouse model, activation of DRD2 inhibits NF- $\kappa B$ nuclear translocation by $\alpha B$-crystalline [19]. We suggest that overexpressed DRD2 also blocks NF-kB nuclear translocation in NSCLC cells. However, the change in NF- $\kappa \mathrm{B}$ nuclear translocation was caused by disruption of $\mathrm{p} 65$ phosphorylation, and a different mechanism may be caused by the discriminating system.

In melanoma, $\beta 3$-adrenergic receptor, another $G$ protein-coupled receptor, mediates the response of tumor cells to the tumor microenvironment, such as hypoxia and ischemia, to enhance melanoma through fibroblasts crosstalk [35]. Phosphorylation at serine 536 plays a pivotal role in regulating p65 nuclear translocation, and serine 276 is required for 


\section{Cellular Physiology Cell Physiol Biochem 2018;48:2258-2272 \begin{tabular}{l|l|l} 
and Biochemistry & $\begin{array}{l}\text { DOI: 10.1159/000492644 } \\
\text { Published online: 15 August, } 2018\end{array}$ & $\begin{array}{l}\text { (c) } 2018 \text { The Author(s). Published by S. Karger AG, Basel } \\
\text { www.karger.com/cpb }\end{array}$
\end{tabular}

recruitment of CREB-binding protein/p300 to p65 for activated transcription [36]. Because DRD2 blocks LPS-induced p65 phosphorylation, the above evidence indicates that DRD2 may abrogate inflammatory stimuli in the microenvironment of NSCLC cells and inhibit cancer cell proliferation.

Taken together, we identified that DRD2 inhibits NSCLC cell growth by inhibiting the NF$\kappa B$ signaling pathway, suggesting a critical role of DRD2 in the development of NSCLC, which further indicates that DRD2 could be a promising immunotherapeutic target in NSCLC.

\section{Acknowledgements}

This work was supported by the National Natural Science Foundation of China (31172043, 31572221, and 81602636), Fundamental Research Funds for the Central Universities (2242015K40034), Nanjing Medical Science and Technology Development Project (ZKX15049), a Jiangsu Postdoctoral Research Grant (1601182B). We thank M. Arico from Liwen Bianji, Edanz Group China (www.liwenbianji.cn/ac), for editing the English text of a draft of this manuscript.

\section{Disclosure Statement}

The authors declare that there are no conflicts of interest.

\section{References}

1 Goldstraw P, Ball D, Jett JR, Le Chevalier T, Lim E, Nicholson AG, Shepherd FA: Non-small-cell lung cancer. Lancet 2011;378:1727-1740.

-2 Torre LA, Bray F, Siegel RL, Ferlay J, Lortet-Tieulent J, Jemal A: Global cancer statistics, 2012. CA Cancer J Clin 2015;65:87-108.

3 Puri S, Chatwal M, Gray JE: Anti PD-L1 combined with other agents in non-small cell lung cancer: combinations with non-immuno-oncology agents. Expert Rev Respir Med 2017;11:791-805.

4 Visconti R, Morra F, Guggino G, Celetti A: The between Now and Then of Lung Cancer Chemotherapy and Immunotherapy. Int J Mol Sci 2017;18.

5 Borcherding DC, Tong W, Hugo ER, Barnard DF, Fox S, LaSance K, Shaughnessy E, Ben-Jonathan N: Expression and therapeutic targeting of dopamine receptor-1 (D1R) in breast cancer. Oncogene 2016;35:3103-3113.

6 Hoeppner LH, Wang Y, Sharma A, Javeed N, Van Keulen VP, Wang E, Yang P, Roden AC, Peikert T, Molina JR, Mukhopadhyay D: Dopamine D2 receptor agonists inhibit lung cancer progression by reducing angiogenesis and tumor infiltrating myeloid derived suppressor cells. Mol Oncol 2015;9:270-281.

7 Roy S, Lu K, Nayak MK, Bhuniya A, Ghosh T, Kundu S, Ghosh S, Baral R, Dasgupta PS, Basu S: Activation of D2 Dopamine Receptors in CD133+ve Cancer Stem Cells in Non-small Cell Lung Carcinoma Inhibits Proliferation, Clonogenic Ability, and Invasiveness of These Cells. J Biol Chem 2017;292:435-445.

$>8$ Li J, Yao QY, Xue JS, Wang LJ, Yuan Y, Tian XY, Su H, Wang SY, Chen WJ, Lu W, Zhou TY: Dopamine D2 receptor antagonist sulpiride enhances dexamethasone responses in the treatment of drug-resistant and metastatic breast cancer. Acta Pharmacol Sin 2017;38:1282-1296.

-9 Sarkar C, Chakroborty D, Dasgupta PS, Basu S: Dopamine is a safe antiangiogenic drug which can also prevent 5-fluorouracil induced neutropenia. Int J Cancer 2015;137:744-749.

10 Senogles SE: D2 dopamine receptor-mediated antiproliferation in a small cell lung cancer cell line, NCI-H69. Anticancer Drugs 2007;18:801-807.

11 Pivonello C, Rousaki P, Negri M, Sarnataro M, Napolitano M, Marino FZ, Patalano R, De Martino MC, Sciammarella C, Faggiano A, Rocco G, Franco R, Kaltsas GA, Colao A, Pivonello R: Effects of the single and combined treatment with dopamine agonist, somatostatin analog and mTOR inhibitors in a human lung carcinoid cell line: an in vitro study. Endocrine 2017;56:603-620. 


\section{Cellular Physiology Cell Physiol Biochem 2018;48:2258-2272 \begin{tabular}{l|l|l|l} 
and 2018 The Author(s). Published by S. Karger AG, Basel \\
\hline
\end{tabular} and Biochemistry

12 Oeckinghaus A, Hayden MS, Ghosh S: Crosstalk in NF- $\mathrm{B}$ signaling pathways. Nat Immunol 2011;12:695708.

13 Deng J, Fujimoto J, Ye XF, Men TY, Van Pelt CS, Chen YL, Lin XF, Kadara H, Tao Q, Lotan D, Lotan R: Knockout of the tumor suppressor gene Gprc5a in mice leads to NF-kappaB activation in airway epithelium and promotes lung inflammation and tumorigenesis. Cancer Prev Res (Phila) 2010;3:424-437.

-14 Jin X, Wang Z, Qiu L, Zhang D, Guo Z, Gao Z, Deng C, Wang F, Wang S, Guo C: Potential biomarkers involving IKK/RelA signal in early stage non-small cell lung cancer. Cancer Sci 2008;99:582-589.

15 Chen W, Li Z, Bai L, Lin Y: NF-kappaB in lung cancer, a carcinogenesis mediator and a prevention and therapy target. Front Biosci (Landmark Ed) 2011;16:1172-1185.

16 Shigdar S, Li Y, Bhattacharya S, O’Connor M, Pu C, Lin J, Wang T, Xiang D, Kong L, Wei MQ, Zhu Y, Zhou S, Duan W: Inflammation and cancer stem cells. Cancer Lett 2014;345:271-278.

$\checkmark 17$ Jeong J, Park YU, Kim DK, Lee S, Kwak Y, Lee SA, Lee H, Suh YH, Gho YS, Hwang D, Park SK: Cdk5 phosphorylates dopamine D2 receptor and attenuates downstream signaling. PLoS One 2013;8:e84482.

18 Zhong H, Voll RE, Ghosh S: Phosphorylation of NF- $\kappa$ B p65 by PKA stimulates transcriptional activity by promoting a novel bivalent interaction with the coactivator CBP/p300. Mol Cell 1998;1:661-671.

19 Zhang Y, Chen Y, Wu J, Manaenko A, Yang P, Tang J, Fu W, Zhang JH: Activation of Dopamine D2 Receptor Suppresses Neuroinflammation Through alphaB-Crystalline by Inhibition of NF-kappaB Nuclear Translocation in Experimental ICH Mice Model. Stroke 2015;46:2637-2646.

-20 Malapelle U, Morra F, Ilardi G, Visconti R, Merolla F, Cerrato A, Napolitano V, Monaco R, Guggino G, Monaco G, Staibano S, Troncone G, Celetti A: USP7 inhibitors, downregulating CCDC6, sensitize lung neuroendocrine cancer cells to PARP-inhibitor drugs. Lung Cancer 2017;107:41-49.

21 Mascolo M, Ilardi G, Romano M, Celetti A, Siano M, Romano S, Luise C, Merolla F, Rocco A, Vecchione M, De RG, Staibano S: Overexpression of chromatin assembly factor-1 p60, poly(ADP-ribose) polymerase 1 and nestin predicts metastasizing behaviour of oral cancer. Histopathology 2012;61:1089-1105.

-22 Hou Z, Zhao W, Zhou J, Shen L, Zhan P, Xu C, Chang C, Bi H, Zou J, Yao X, Huang R, Yu L, Yan J: A long noncoding RNA Sox2ot regulates lung cancer cell proliferation and is a prognostic indicator of poor survival. Int J Biochem Cell Biol 2014;53:380-388.

23 Zhao W, Chang C, Cui Y, Zhao X, Yang J, Shen L, Zhou J, Hou Z, Zhang Z, Ye C, Hasenmayer D, Perkins R, Huang X, Yao X, Yu L, Huang R, Zhang D, Guo H, Yan J: Steroid receptor coactivator-3 regulates glucose metabolism in bladder cancer cells through coactivation of hypoxia inducible factor 1 alpha. J Biol Chem 2014;289:11219-11229.

24 Xu P, Cai F, Liu X, Guo L: Sesamin inhibits lipopolysaccharide-induced proliferation and invasion through the p38-MAPK and NF- $\kappa$ B signaling pathways in prostate cancer cells. Oncol Rep 2015;33:3117-3123.

-25 Wang L, Zhu R, Huang Z, Li H, Zhu H: Lipopolysaccharide-induced toll-like receptor 4 signaling in cancer cells promotes cell survival and proliferation in hepatocellular carcinoma. Dig Dis Sci 2013;58:2223-2236.

-26 Siegel RL, Miller KD, Jemal A: Cancer Statistics, 2017. CA Cancer J Clin 2017;67:7-30.

27 Pramana A, Descallar J, Vinod S: A decade of community-based outcomes of patients treated with curative radiotherapy with or without chemotherapy for non-small cell lung cancer. Asia Pac J Clin Oncol 2016;12:e357-366.

-28 Thomas R: Understanding immunotherapy for the treatment of non-small cell lung cancer. Br J Nurs 2016;25:S12-17.

-29 Pornour M, Ahangari G, Hejazi SH, Ahmadkhaniha HR, Akbari ME: Dopamine receptor gene (DRD1-DRD5) expression changes as stress factors associated with breast cancer. Asian Pac J Cancer Prev 2014;15:1033910343.

-30 Li L, Miyamoto M, Ebihara Y, Mega S, Takahashi R, Hase R, Kaneko H, Kadoya M, Itoh T, Shichinohe T, Hirano S, Kondo S: DRD2/DARPP-32 expression correlates with lymph node metastasis and tumor progression in patients with esophageal squamous cell carcinoma. World J Surg 2006;30:1672-1679.

-31 Gemignani F, Landi S, Moreno V, Gioia-Patricola L, Chabrier A, Guino E, Navarro M, Cambray M, Capella G, Canzian F: Polymorphisms of the dopamine receptor gene DRD2 and colorectal cancer risk. Cancer Epidemiol Biomarkers Prev 2005;14:1633-1638.

-32 Murphy G, Cross AJ, Sansbury LS, Bergen A, Laiyemo AO, Albert PS, Wang Z, Yu B, Lehman T, Kalidindi A, Modali R, Schatzkin A, Lanza E: Dopamine D2 receptor polymorphisms and adenoma recurrence in the Polyp Prevention Trial. Int J Cancer 2009;124:2148-2151. 


\section{Cellular Physiology Cell Physiol Biochem 2018;48:2258-2272

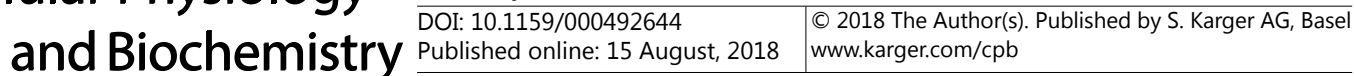

Wu et al.: DRD2 Inhibits NSCLC Progression by Abrogation of NF-KB Pathway

-33 Campa D, Zienolddiny S, Lind H, Ryberg D, Skaug V, Canzian F, Haugen A: Polymorphisms of dopamine receptor/transporter genes and risk of non-small cell lung cancer. Lung Cancer 2007;56:17-23.

-34 Kawase A, Yoshida J, Ishii G, Nakao M, Aokage K, Hishida T, Nishimura M, Nagai K: Differences between squamous cell carcinoma and adenocarcinoma of the lung: are adenocarcinoma and squamous cell carcinoma prognostically equal? Jpn J Clin Oncol 2012;42:189-195.

-35 Calvani M, Pelon F, Comito G, Taddei ML, Moretti S, Innocenti S, Nassini R, Gerlini G, Borgognoni L, Bambi F, Giannoni E, Filippi L, Chiarugi P: Norepinephrine promotes tumor microenvironment reactivity through beta3-adrenoreceptors during melanoma progression. Oncotarget 2015;6:4615-4632.

-36 Sasaki CY, Barberi TJ, Ghosh P, Longo DL: Phosphorylation of RelA/p65 on serine 536 defines an ІкB $\alpha$ independent NF-кB pathway. J Biol Chem 2005;280:34538-34547. 